\title{
Capability Assessment of Women Self Help Groups of Uttarakhand
}

\author{
Anjali Chunera* and Neelam Bhardwaj \\ Department of Agricultural Communication, G. B. Pant University of Agriculture and \\ Technology, Pantnagar, Uttarakhand, India \\ *Corresponding author
}

\section{Keywords \\ Self Help Groups, women, capability assessment, development \\ Article Info \\ Accepted: \\ 14 August 2019 \\ Available Online: \\ 10 September 2019}

\section{A B S T R A C T}

This study was conducted with the objective to assess the capability of selected women Self Help Groups (SHGs) in Nainital district of Uttarakhand. For the purpose of the study ten sample women SHGs were selected through PPS (Probability Proportional to Size) sampling method. The study was descriptive in nature relied both on quantitative and qualitative data. On the basis of the findings it is concluded that majority of SHGs were rated good in organizational capacity and financial management capability, rated as moderate in savings and credit capability, awareness capability and in plans and visions capability and rated weak in micro-enterprise development capability, skill development capability, empowerment and influences capability and networks and linkages capability. The overall capability of majority of the SHGs were rated as moderate. Therefore, extensive effort and support are required to improve the capability of the SHGs. Continuous trainings on capability building, skill development, personality development, leadership development, achievementmotivation training, technical training orientation and entrepreneurial skills development etc are needed to help them to enhance their capability and mind-sets. Both the government and private agencies have to play a coordinated role with an integrated approach for making the movement of women SHGs development a success.

\section{Introduction}

Women in rural India are disproportionately disadvantaged. They are the most underprivileged and vulnerable section of the society and constitute a sizeable segment of those who belong to the below poverty line (Mathew, 2000). Even at present in various sectors women are not given importance and are not treated as equal to men (Anju and Chakkachamparabil 2018, Sugaraj and Salve
2014, Stalin 2017). There are several instances where women have proven their presence in different fields, but still, are not given recognition in the mainstream of development. Also, they are not provided wth opportunities same as men. Their literacy rates are lower than those of men in India.

The male literacy rate is 82.14 per cent and female literacy rate is 65.46 per cent according to Census 2011. 
Self help groups (SHGs) are the most recent advancement which encourages them to come forward and make them competent and selfemployed. SHGs are playing a significant role in raising the level of income and thereby lifting their standard of living by providing them self-employment opportunites. The groups give the women the opportunities of self-development through imparting them education, training and practical knowledge (Gopalaraju and Kumar 2010). In India, the number of SHGs has increased from 14,317 in 1997-98 to 2305513 as on 31.07.2015. (NRLM). Self help groups in India have endowed thousands of rural poor, especially women, not only with platforms to work together to solve common problems but also financial accessibility (Keshava et al., 2010). With the increasing awareness, large numbers of vulnerable group of women are joining these groups. Many women have preferred SHGs as an auxiliary source of earning. SHGs have emerged as a copper-bottomed tool to provide employment opportunities and empowerment to poor women.

The SHG movement's initial success has drawn considerable attention of policymakers, development practitioners, fund providers, academicians, researchers, and even corporate bodies. The trend shows a large amount of flood in terms of number of SHGs in the Uttarakhand state but the end objective of maintaining quality of SHGs is not fulfilled (Chakraborty 2006). The most important reason behind degrading quality is the lack of capabilities of the SHGs which are essential for their functioning (Das and Bhowal 2012). The SHGs today have become a vehicle to pursue diverse developmental agenda and even for the profit motive.

To avert such a situation, growth with quality has become the paramount agenda of today among different stakeholders, as there is an overreaching concern about the sustainability of the SHG movement in India. In other words, the proliferation of SHG has posed a serious challenge to sustain this movement by maintaining quality of SHG and hence, the quality assessment of SHGs is now being considered as a key concern. Significant financial investment and technical support are required for meeting these challenges.

There was a need to study the prevailing gap between the capability present and required for sustenance, and what are the areas of capability that require strengthening (Chakraborty 2006). It is required to receive an early warning of potential system failure. Therefore capability assessment of SHGs in the country was need of the hour to help address the constraints of SHGs by assessing the core areas of improvement.

\section{Materials and Methods}

This study was conducted with the objective to assess the capability of selected women Self Help Group in two blocks i.e Haldwani and Bhimtal of Nainital district of Uttarakhand. For the purpose of the study ten sample women Self-Help Groups were selected, promoted by block through PPS (Probability Proportional to Size) sampling method. This study is based on primary data collected from interviews and focus group discussions. The study was descriptive in nature relied both on quantitative and qualitative data. In accordance with the objectives of the proposed study interview schedule, interview guide and focus group discussion were used as a tool for data collection. To access the capability of Self Help Groups, Viruthiyel and Goran (2007) modified tool was used which assessed SHGs capability on following parameters: Organizational capacity, savings and credit, financial management, micro-enterprise development, skill development, awareness, empowerment and influence, network and linkages and plans 
and visions. For the purpose of this research descriptive research design was used.

\section{Results and Discussion}

\section{Organizational capacity}

This indicator assessed the organizational capacity of the SHG with following subindicators like maintenance of group records, holding meetings at the stipulated intervals, observance of group norms, evolving group identity, evolving a mechanism for consensus, and rotation of office bearers.

A careful perusal of table 1 shows that in the organizational capacity indicator majority of the SHGs i.e. 70 per cent were rated as good, 20 per cent as weak and only 10 per cent as moderate.

The possible reasons for the good capability of the majority of the SHGs were the cooperation and unity among the members because of the same caste, the strict adherence to the rules and regulation of the group by the members, good understanding among group members and good leadership.

\section{Savings and credit}

This indicator measures the ability of the SHG to take up its savings and lending operations. Seven sub-indicators had been used to measure this capability.

These were: payment of saving contribution by the members, acceptance of contribution in the meeting, loan distribution, whether officebearer took loan after other members, rate of loan recovery, use of loan amount, and freedom from exploitative loans.

It is evident from table 1 that in the savings and credit indicator 60 per cent SHGs were rated as moderate followed by 40 per cent of the SHGs were rated as good. None of the SHG was rated as weak. The possible reasons of the good capability of 40 per cent of SHGs were the understanding and cooperation between the members, the seriousness for the money matters, and pressure from the NGO was a reason for the timely contribution and repayment of loans in the SHG. It was noticed that the reasons for moderate capability were non-cooperative nature of the members, fewer funds, poverty, less interest to continue in membership in SHG and membership in more than one SHG.

\section{Financial management}

Financial management is an essential quality that the group must acquire for long term sustainability. Five sub-indicators were used to assess this capability.

These were: knowledge of members about their savings and loan liability, total group interest earned and default amount, timely maintenance of saving-cum-loan ledger and cashbook, visit of members in the bank, and timely deposition of saving contribution.

As is evident from table 1 that in financial management indicator majority of the SHGs i.e. 70 per cent were rated as good, 30 per cent as moderate and none of the SHG was rated as weak. The reasons for the majority of the good capability of SHGs were the members were concerned about their money, their seriousness in management of finance, trust towards the leader, and educated members.

\section{Micro-enterprise development}

This indicator assessed the group capacity in this sphere with the help of the following five sub-indicators: acquiring new skills after joining SHG, setting up new enterprises, Income generating activities yielding income as per their expectations, micro-enterprises 
running without being constrained, and establishment of linkages for successful working of the enterprise.

A careful perusal of table 1 shows that in the micro-enterprise development majority i.e. 40 per cent of the SHGs were rated as weak whereas equal percentage of SHGs i.e. 30 per cent were rated as good and moderate.

The possible reason for weak capability was lack of proper skill training and loan from the bank, lack of information from the administration and the training given was not of their interest. And the reasons for good and moderate capability were the seriousness and the entrepreneurial nature among the members and the support of NGO in providing training of SHG member's interest and helping in marketing of products.

\section{Skills development}

This is an assessment of the ability of the group to manage its own functions through interaction with service providers, it also assessed whether these group capacities found recognition by other social entities in the community and outside. This was studied under six sub-indicators like conducting meetings without help of any organization, maintaining records without support from any organization, good negotiating power with bank and other institutions, demanding services from NGO/government project, illiterate members learning to read and write, and helping other community members in matters like credit, education, etc.

From table 1, it is evident that in skill development indicator half of the SHGs were rated as weak and others as moderate none of the SHG was rated good.

The reason for the weak and moderate capability of SHGs were dependency on VDO/NGO for basic works, less professional attitude to take initiative or responsibility, less confidence to demand services from NGO and government officials, lacking leadership quality among members and no interest to learn to read and write among old age members.

\section{Awareness}

Working in groups, discussing issues of common interest, working for the common cause and such other activities, group members acquired more forward looking attitudes and become aware of social issues.

These attitudinal changes are an indication of the better capability of the groups, as the SHG movement was beyond a mere saving and lending entity and becomes a tool for social empowerment. Seven sub-indicators were used to assess this aspect. These were: awareness about group goals, pre-natal care of expecting mothers, immunization of newborn infants, healthy nutritional practices, the legal age of marriage, small family norm, causes of diarrhea, jaundice, and malaria and their prevention, and education of girl child.

The data in table 1 reveals that in the awareness indicator majority i.e. 60 per cent of the SHG were rated as moderate, 30 per cent as good and only 10 per cent were rated as weak.

The possible reasons for weak and moderate capability i.e. $70 \%$ were poor education of the members and unawareness on nutritional aspects.

It was noticed that the level of awareness and the attitude of the members have changed in a positive way after joining the NGO and SHGs and in thirty per cent of the SHGs members become aware after holding discussion with educated members of the SHGs. 


\section{Empowerment and influences}

The empowerment of the groups was measured on the nine sub-indicators. The relevant sub-indicators were as follows: improvement in decision making power of members in the family, disposing their income by own choice, participation in gram sabha meeting, participation in gram panchayat election, campaigning for improving village institution and demolishing social evil, lobbing with panchayat and administrative authority for solving common problem and promoting other people to form SHG.

The data in table 1 shows that fifty per cent of the SHGs were found to be weak on empowerment and influence. Only 40 per cent were having moderate empowerment and only one of the SHG was found to have good empowerment.

The possible reasons for maximum percentage of weak and moderate capability were lack of interest on social issues and campaigning, the restrictions from the family, lack of confidence to meet higher authorities and to carry out campaigns, low awareness, less education, poverty and less education, ignorance of government officials and a way of thinking that it is not their job. The reason for good capability was support from the family.

\section{Networks and linkages}

This component included five sub-indicators like linkages of SHG with line departments at the block level, DRDA/other agency for information and support, networks with other neighboring SHGs and organization of community events on special occasions. Groups worked better when they develop linkages with other institutions.
The data in table 1 clearly reveals that all the SHGs i.e. 100 per cent were rated as weak. The possible reasons were the lack of confidence to contact government officials, education, less interest of some members to continue working in SHG.

The findings are in line with the findings of Sowjanya (2007) who observed that majority of the Self Help Groups had never linked with bank and agricultural office and therefore had weak linkages with them.

\section{Plans and visions}

This component included five sub-indicators related to SHG's future plans like plans to improve corpus fund, diversify incomegenerating activities, plans to increase social activities, utilize/invest its surpluses, and plans to sustain itself without support from any project.

From the table 1, it can be analyzed that in the plans and visions indicator majority i.e. 60 per cent of the SHGs were rated as moderate followed by 30 per cent SHGs as weak and only 10 per cent SHGs as good.

The possible reasons for the majority of the groups to have moderate and weak capability i.e. $90 \%$ reported to receive no skill-oriented trainings and the poor financial condition of the group members, due to which they could not invest more.

\section{Overall Capability Index}

The data in table 2 shows the overall Capability Index of the SHGs. Majority i.e. 60 per cent of the SHGs were rated as moderate followed by 20 per cent SHGs were rated weak and 20 per cent as good. 
Table.1 Distribution of Self Help Groups

$(\mathrm{n}=10)$

\begin{tabular}{|c|c|c|c|c|}
\hline S.No. & Parameter & Rating & Frequency & Percentage \\
\hline \multirow{3}{*}{1.} & \multirow{3}{*}{$\begin{array}{l}\text { Organizational } \\
\text { capacity }\end{array}$} & Weak (0-4) & 2 & 20 \\
\hline & & Moderate (4.5-7.5) & 1 & 10 \\
\hline & & Good (7.5-10) & 7 & 70 \\
\hline \multirow{3}{*}{2.} & \multirow{3}{*}{$\begin{array}{l}\text { Savings and } \\
\text { credit }\end{array}$} & Weak (0-4) & - & - \\
\hline & & Moderate (5-7) & 6 & 60 \\
\hline & & Good (8-10) & 4 & 40 \\
\hline \multirow{3}{*}{3.} & \multirow{3}{*}{$\begin{array}{l}\text { Financial } \\
\text { management }\end{array}$} & Weak (0-4) & - & - \\
\hline & & Moderate (5-7) & 3 & 30 \\
\hline & & Good (8-10) & 7 & 70 \\
\hline \multirow{3}{*}{4.} & \multirow{3}{*}{$\begin{array}{l}\text { Micro- } \\
\text { enterprise } \\
\text { development }\end{array}$} & Weak (0-2) & 4 & 40 \\
\hline & & Moderate (4-6) & 3 & 30 \\
\hline & & Good (8-10) & 3 & 30 \\
\hline \multirow{3}{*}{5.} & \multirow{3}{*}{$\begin{array}{l}\text { Skills } \\
\text { development }\end{array}$} & Weak $(0-4)$ & 5 & 50 \\
\hline & & Moderate (4.5-7) & 5 & 50 \\
\hline & & Good (8-10) & - & - \\
\hline \multirow{3}{*}{6.} & \multirow[t]{3}{*}{ Awareness } & Weak (0-4) & 1 & 10 \\
\hline & & Moderate (4.5-7.5) & 6 & 60 \\
\hline & & Good (8-10) & 3 & 30 \\
\hline \multirow{3}{*}{7.} & \multirow{3}{*}{$\begin{array}{l}\text { Empowerment } \\
\text { and influences }\end{array}$} & Weak (0-3) & 5 & 50 \\
\hline & & Moderate (4-6) & 4 & 40 \\
\hline & & Good (7-10) & 1 & 10 \\
\hline \multirow{3}{*}{8.} & \multirow{3}{*}{$\begin{array}{l}\text { Networks and } \\
\text { linkages }\end{array}$} & Weak (0-3) & 10 & 100 \\
\hline & & Moderate (4-6) & - & - \\
\hline & & Good (7-10) & - & - \\
\hline \multirow{3}{*}{9.} & \multirow{3}{*}{$\begin{array}{l}\text { Plans and } \\
\text { visions }\end{array}$} & Weak (0-2) & 3 & 30 \\
\hline & & Moderate (4-6) & 6 & 60 \\
\hline & & Good (8-10) & 1 & 10 \\
\hline
\end{tabular}


Table.2 Distribution of Self Help Groups on the basis of their overall capability index

\begin{tabular}{|l|l|l|l|}
\hline S. No. & Rating & Frequency & Percentage \\
\hline 1. & $0-4=$ Weak & 2 & 20 \\
\hline 2. & $4-7=$ Moderate & 6 & 60 \\
\hline 3. & $7-10=$ Good & 2 & 20 \\
\hline
\end{tabular}

The findings are in line with the findings of Das (2010) and Das (2010) who revealed that a large number of groups had low to medium capability.

\section{Suggestions for improving capability for SHGs}

The findings revealed that weak areas of capability for maximum SHGs were microenterprise development, skill development, empowerment and influences, and networks and linkages. Therefore these findings can be utilized by development departments for framing trainings for SHGs as these areas require more attention. It is important to make them aware about the benefits of network for getting access to resources and promotional schemes. Marketing facilities for the purpose of buying and selling of both raw material and finished goods should be provided in easy reach.

It was found that delay in sanctioning of the loan was the major problem reported by the majority of the SHGs. Some of SHGs added that unprofessional attitude of the members, less education, time management were other constraints. And few members reported that trainings were not of their interest and lack of information as a problem. So these findings can be utilized in organizing trainings on various topics for SHG members.

The findings will also help the extension policymakers to formulate appropriate policies and programs for strengthening SHGs and meeting inadequacies of these groups.

Training should be supported by extension service and adequate supply of inputs, even after the completion of the training, and the training institution should maintain close contacts with the trainees in order to assess their performance or ascertain their problems if any.

Some of the SHG beneficiaries had no clear idea about thrift and loans. They have to be educated and awareness has to be created with regard to the process of these schemes. Also the loan granting procedures and formalities of the bank should be simplified and the required documents should be minimized.

Awareness programs are to be conducted to the members regarding health, education and environmental conditions. Giving them orientation, induction training and acquaint them with the objectives and some of the principles of working in groups and in the community would go a long way for their success. There should be regular monitoring and effectively follow up of the unit. On the basis of the findings it is concluded that majority of SHGs were rated good in organizational capacity and financial management capability, rated as moderate in savings and credit capability, awareness capability and in plans and visions capability and rated weak in micro-enterprise 
development capability, skill development capability, empowerment and influences capability and networks and linkages capability. It was also observed that in Overall Capability Index majority of the SHGs were rated as moderate. Therefore, extensive effort and support are required to improve the capability of the SHGs. Continuous trainings on capability building, skill development, personality development, leadership development, achievement-motivation training, technical training orientation, and entrepreneurial skills development etc are needed to help them to enhance their capability and mind-sets. Both the government and private agencies have to play a coordinated role with an integrated approach for making the movement of women SHGs development a success.

\section{References}

Anju, P. A. and Chakkachamparabil, E. P. 2018. Problems encountered by women Entrepreneurs: with special reference to Thrissur district. Vistas, 7(1): 16-27.

Chakraborty, M. 2006.A note on microfinance in Uttarakhand. [Cited from www.mixmarket.org]

Das, B.C. 2010. Performance of SGSY-SHG linked to RRB in Karnataka. Economic Affairs, 55(3\&4): 201-207.

Das, S. K. 2010. Ground realities of Self Help Group-Bank linkage programme: An empirical analysis. International Journal of Research in Social Sciences, 2(2): 464-479.

Das, S. K. and Bhowal, A. 2012. Quality Assessment Parameters of Self Help Group's: A Psychometrics Analysis of Stakeholders' Perception. Journal of Finance and Economics, 1(4): 69-83.

Sowjanya. 2007. A comparative analysis of successful and unsuccessful Self Help Groups in Gadag district of Karnataka. Published master's thesis, University of Agriculture Sciences, Dharwad.

Stalin A. 2017.Women Entrepreneurs in Tamilnadu: Problems and Challenges. International journal of scientific research and education, 5(11):77397748 .

Sugaraj J. M. and Salve P.S. 2014. Constraints/Challenges Faced In a Journey of Women Entrepreneurship in the Development in Western Maharashtra, Journal of Economics and Finance, 3 (2): 2321-5933.

Viruthiyel, J. and Goran, J. 2007. Capability assessment of Self Help Groups. [Cited from - http://www. hcfp.gov.in/]

\section{How to cite this article:}

Anjali Chunera and Neelam Bhardwaj 2019. Capability Assessment of Women Self Help Groups of Uttarakhand. Int.J.Curr.Microbiol.App.Sci. 8(09): 1205-1212.

doi: https://doi.org/10.20546/ijcmas.2019.809.138 